\title{
THE CASE OF NOWE WARPNO - NEW DIMENSION OF UNDERWATER RESEARCH IN THE SZCZECIN LAGOON
}

\author{
PRZYPADEK NOWEGO WARPNA - \\ NOWY WYMIAR BADAŃ PODWODNYCH \\ NA ZALEWIE SZCZECIŃSKIM
}

Przemysław Krajewski

Katedra Archeologii, Uniwersytet Szczeciński ul. Krakowska 71-79, 71-017 Szczecin, Poland p.kraj@univ.szczecin.pl

\section{Marta Chmiel}

Katedra Archeologii, Uniwersytet Szczeciński ul. Krakowska 71-79, 71-017 Szczecin, Poland chmiel.marta86@gmail.com

Michat Adamczyk

Katedra Archeologii, Uniwersytet Szczeciński ul. Krakowska 71-79, 71-017 Szczecin, Poland michal.adamczyk.us@gmail.com

\begin{abstract}
Following paper presents a new aspect of the study of submerged landscapes in the Szczecin Lagoon. This aspect is the importance of coastal processes for the conservation status of the sites and archaeological contexts.

Underwater prospection can lead to collection of archaeological material of an entirely different character. These artifacts may in fact come from the destroyed land erosion processes (abrasion), and so - in terms of methodology of archeology - lie on the secondary deposit. Of course, cognitive value of such sources is very different than artifacts found in full context. However, there is possibility to use them not only to study archeology, but to assess the scale, pace and extent of coastal phenomena perceived as post-depositional processes.
\end{abstract}

KEY WORDS: Coastal sites, Coastal processes, Szczecin Lagoon, Late Palaeolithic/Mesolithic, Early Iron Age, Post-Medieval Period. 


\section{INTRODUCTION}

This article presents a new aspect of research on submerged landscapes in the Szczecin Lagoon in Poland. All work discussed herewith was carried out by Szczecin University as part of the project Archaeological and paleoenvironmental study of submerged landscapes in the Szczecin Lagoon and the Pomeranian Bay. The project resulted from our participation in the European collaborative research programme SPLASHCOS - Submerged Prehistoric Archaeology and Landscapes of the Continental Shelf.

Submerged landscapes are vast areas of contemporary shelf - i.e. shallow offshore areas which used to be terra firma in the past. Over the last one million years the level of the world ocean was lower by circa $130 \mathrm{~m}$. Hence, the ancestors of the homo species, and later the homo themselves were able to settle vast areas of seaside lowlands. Between 16.000 and 6.000 BP the water lever rose in a series of transgressions submerging a substantial part of this area. It is such 'submerged landscapes' that are becoming the subject of intensive research carried out by experts from a variety of academic disciplines including oceanography, marine geology, palaeography or finally archaeology. Together we seek to answer various questions concerning, among other things, the time, scale and course of marine transgressions, but also the traces of human activity or human presence within the submerged territories.

However, not only transgressions were responsible for shaping coastlines of oceans and seas. In the area under our investigation also the currently ongoing processes are important. However, the deeper understanding of their significance for the archaeology of submerged landscapes requires referring to the results of long-term geographical research.

The changeability of the coastline of the southern Baltic has been the subject to paleogeographic studies (e.g. Spethman 1906) for more than 100 years now. The thread of thought focussing on paramount changes, resulting from successive transgressions has been continued until today (e.g. Miotk-Szpiganowicz, Uścinowicz, Przeździecki and Jegliński 2009). Of specific nature are also isostatic processes, genetically associated with Pleistocene, although possible to observe also in present times. These processes are responsible for submerging the coastline of the southern Baltic at a rate which exceeds 1 millimetre per year (cf. Lampe 2002, p.17, fig. 2).

Less spectacular in their effects than marine transgressions are other processes responsible for shaping the coastline. Among them are, for example, the processes of cliff abrasion and the transport and accumulation of marine sediments carried by sea currents. The resulting changes to the coastline of Wolin Island are estimated to be ca 226 m over the past 350 years (Piasecki 1966) while for the beach in Świnoujście the rate of change is about 2 meters per year (Łabuz 2007).

The significance of cliff abrasion need not be limited to the quantitative aspects only, i.e. the area of land lost. The saturation of the coastline with buildings and structures associated with economy, production, tourism may lead to very serious consequences for economy or settlement. Hence, extensive research is currently pursued 
to determine not only what the coastline looked like in the past, but also to observe its current condition and to forecast how it may change in the future (DudzińskaNowak 2007).

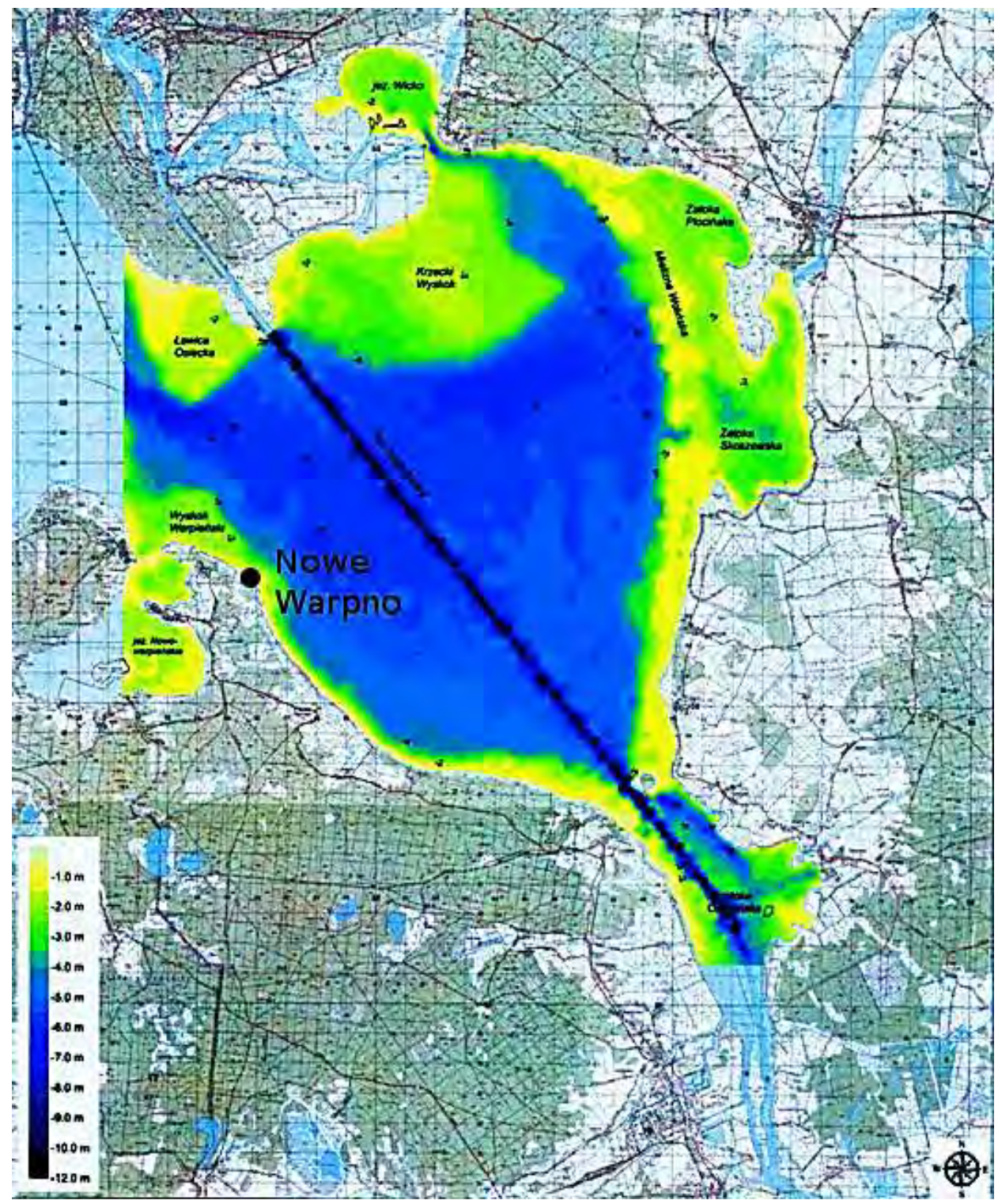

Fig. 1. Map of Szczecin Lagoon Area with bathymetry and location of Nowe Warpno site

Ryc. 1. Mapa batymetryczna Zalewu Szczecińskiego z oznaczoną lokalizacją stanowiska w Nowym Warpnie 


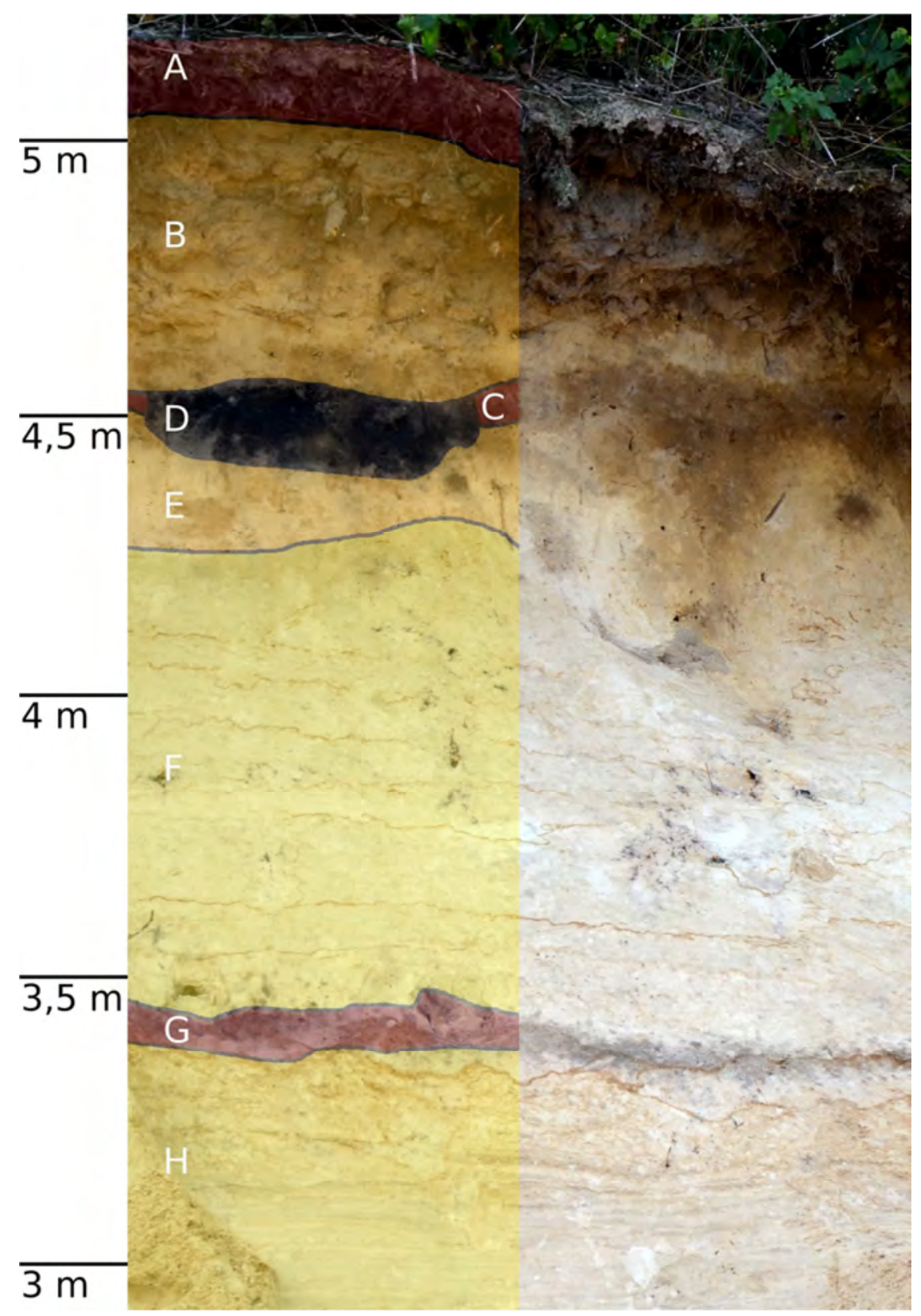

Fig. 2. Stratigraphy of the cliff. A - Modern humic layer; B - Holocene sands; C - Holocene paleosoil; D - Younger hearth; E - Holocene sands (?); F - Younger Dryas aeolian sands; G - Allerød paleosoil; $\mathrm{H}$ - Older Dryas aeolian sands. Heights are in meters ASL

Ryc. 2. Stratygrafia klifu. A - współczesny humus; B - piaski holoceńskie; C - holoceńska gleba kopalna; D - młodsze palenisko; E - piaski holoceńskie (?); D - piaski eoliczne, młodszy Dryas; G - allerødzka gleba kopalna; $\mathrm{H}$ - piaski eoliczne, starszy Dryas (wysokości podane w m n.p.m.) 
It is surprising, however, that this kind of research focuses predominantly on the sea-coast. The Szczecin Lagoon, which is a basin whose coastline is nearly $240 \mathrm{~km}$ long, may also allow for observing various processes that are of great importance both for the present day and for archaeology.

In this context it is worth recalling the example of the village of Lubin located on the south-west end of Wolin Island. The layout of its today's communication system points out that its centre was originally located further west, in the area currently submerged by the Lagoon. Lubinus' map from the $17^{\text {th }}$ century clearly shows the location of the village of Lubin far from the Lagoon (Schoeneich 1964, pp. 14-15). Hence even a minor change to the coastline can result in paramount changes to the layout of a settlement. This remark is even more relevant with reference to spatial contexts of archaeological sites. For instance, the early medieval stronghold in Lubin, must have been located hundreds of meters from the edge of the cliff at the time of its functioning. This remark is even more relevant in relation to the Lusatian stronghold located in the same village, which is currently slipping into the Lagoon, but in the past was undoubtedly located in considerable distance from it.

The presence of an active cliff could also result in the uncovering of new archaeological sites, which were previously unknown either because they are convered by contemporary buildings or structures, or because of the geological past of that particular stretch of the coastline. Such a situation could be observed in the area of Nowe Warpno.

\section{THE CASE OF NOWE WARPNO}

Nowe Warpno is a village located in the western part of the Szczecin Lagoon. The stretch of coastline in question is in the form of a cliff cutting through a series of Aeolian covers deposited on earlier Pleistocene formations. A few layers of Paleosoils have been established on the cliff, but we were primarily interested in archaeological materials deposited at the bottom of the cliff as well as in flat shoals up to 20-30 meters away from this exposition. Therefore, various research procedures were implemented with the purpose of establishing the range of their occurrence and the features of their dispersion, as well as geological (stratfication) and anthropogenic context. It soon became clear, that the major contexts which the registered sources originally referred to, are located on the cliff, and not on the beach at its bottom. Hence, most of the field research concentrated in that area.

\section{RESEARCH IN NOWE WARPNO}

Carrying out archaeological research on an active cliff is not an easy undertaking. The coastile is subject to special protection regulations and therefore it is not possible to excavate it in a manner typical for archaeological works conducted 
elsewhere. Hence no trench could be laid out to be excavated horizontally within stratigraphically defined layers. In fact, exploration is limited to the absolute minimum. Its scope is defined by the necessity to prepare the natural exposition of the cliff for documention.

Works undertaken on the cliff helped to distinguish four layers of paleosoils. The two younger paleosoils were interpreted as the result of damage to plant life in contemporary times. They might be associated with forestry (logging activities). Two older layers of paleosoils were found to be very interesting from the point of view of archaeology, especially given the fact in the direct context of one of them a clearly visible archaeological feature was observed. The prepared and cleared profile was recorded, and samples were collected from the oldest soil layer and the fills for paleoenvironmental research and dating. Palynological analysis and dating using AMS method were carried out. Moreover, a collection of portable sources deposited on the beach and in flat shoals was gathered. The collected material was subject to technological analysis.

\section{PALYNOLOGICAL ANALYSIS}

In the unanimous opinion of specialists, the contexts from which the samples for palynological analysis were collected raised hopes for interesting results. Expectations were even grater after receiving the results of absolute dating (see below). Unfortunately, laboratory procedures aimed at the preparation of microscopic samples of sporomorphs did not yield any results, as it turned out that palynologic samples are almost sterile. This seems to result from post-depositional processes taking place within the dune.

\section{AMS DATING}

Three samples were subject to radiocarbon dating. One was from paleosoil, the other two from finds identified in the cliff. The research carried out in Poznań Radiocarbon Laboratory provided the following results:

$-11060 \pm 60$ BP [Poz-44487], paleosoil: $11001 \pm 107 \mathrm{BC}$ cal;

$-8700 \pm 50 \mathrm{BP}[\mathrm{Poz}-44489]$, older hearth: $7717 \pm 77 \mathrm{BC}$ cal;

$-2430 \pm 35$ BP [Poz-44488], younger hearth: $575 \pm 129 \mathrm{BC}$ cal

(All dates were calibrated using CalPal_2007_HULU curve: U. Danzeglocke, O. Jöris, B. Weninger, 2012. CalPal-2007 $7^{\text {olline }}$. http://www.calpal-online.de/, accessed 201202-04).

The results presented above allow for distinguishing at least two settlement periods. The first of these was established on the basis of dates from the older hearth and points to the Middle Mesolithic period, and more specifically the Maglemose 
Culture. The other period has been dated to Early Iron Age and ought to be connected with the Lusatian culture. The results discussed were later correlated with archaeological finds.

\section{PORTABLE ARCHAEOLOGICAL SOURCES}

During the research conducted on the cliff, the beach and in the seafront areas within the site a collection of flint artefacts and fragments of pottery were gathered. The finds were initially divided into categories. In case of flint finds, the basis for dividing the inventory is the analysis of their distinctive features. This method was developed on the basis of experimental works and the analysis of source material published by other authors. Among them studies on the technique of long blade production (Pelegrin 2006), studies on Maglemosian blade technologies (Sørensen 2006), a study on the predefined blade production (Migal 2007) as well as studies on the methods of production of blades from Pomeranian flint (Płaza and Grużdź 2010) need to be mentioned.

The analytic approach applied in this study is based on the presumption of classificatory coherence of the assemblages, which were grouped with regard to the framework of the percussion technique and methods. Among the basic features allowing for the identification of the technique are primarily those that are distinctive in the case of debitage, such as the form of butt, striking platform, the presence and the clarity of ripples and fissures, platform angle, etc.

A separate category is made up of features deriving from the method applied. Primarily all technological measures preceding the percussion are taken into consideration. These measures may be aimed at correcting of the core angle (abrasion, faceting), butt isolation, correcting of the profile of debitage or the correction of the platform (rejuvenation, core tablet removal). The negative scar pattern on dorsal sides of blades and surfaces of cores is also of great significance.

Three assemblages of flint finds have been distinguished on the basis of technological analysis. A similar procedure was applied with regard to pottery and it allowed for distinguishing two groups of pottery, one of which can be associated (correlated) with one of the assemblages of flint finds.

\section{FLINT FINDS}

\section{Assemblage I: Direct percussion blades}

This is the most important assemblage of finds collected at the site. This group consists of one core and 15 blades and their parts. Debitage features, such as clearly visible points of percussion, as well as clear but wide butts and soft ripples suggest 

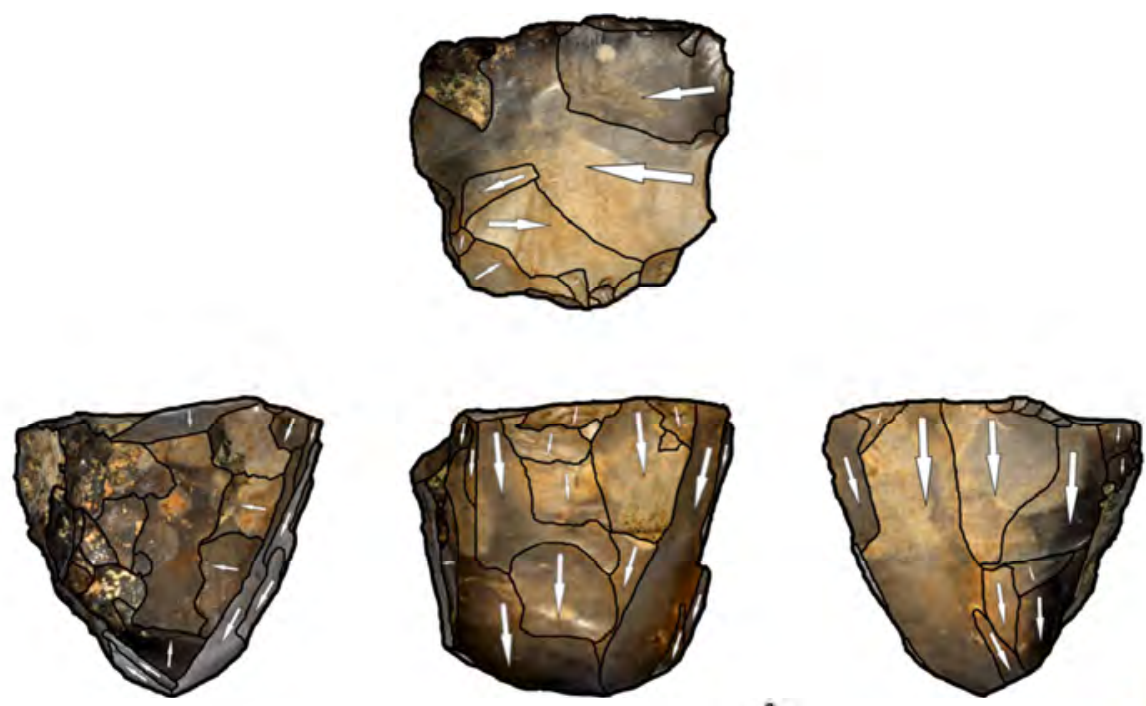

I
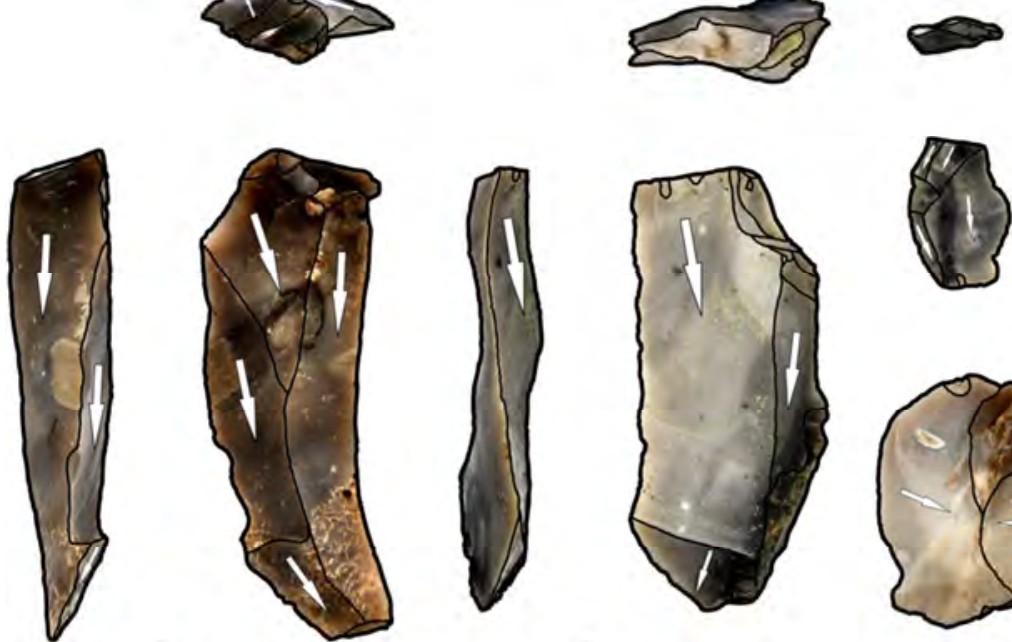
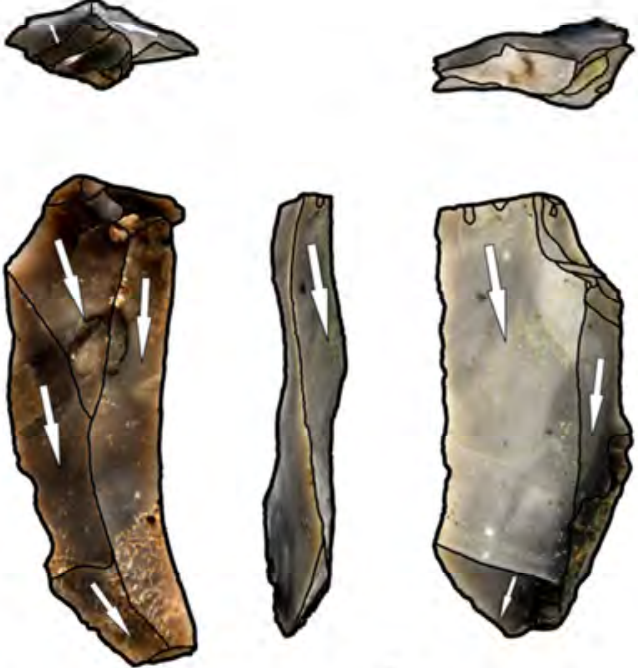

2
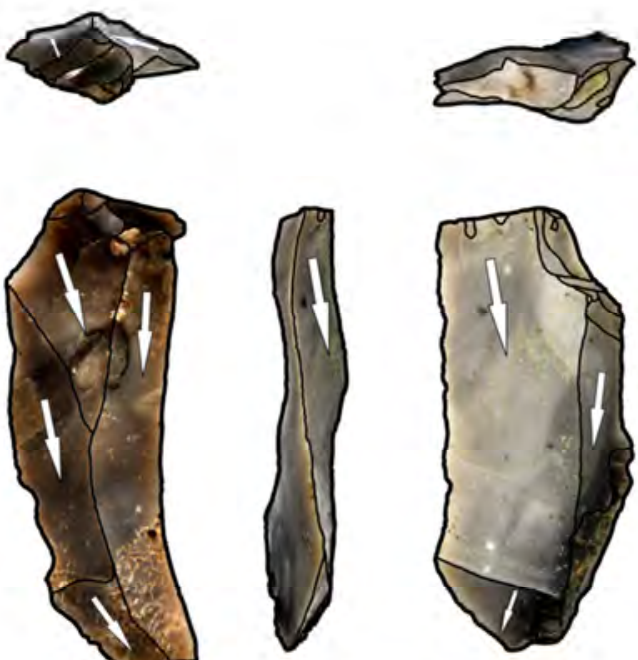

3

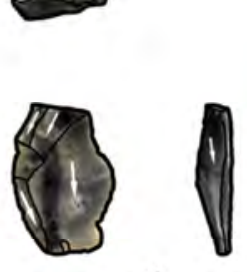

4

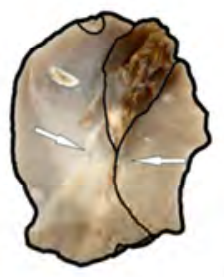

5

Fig. 3. Lithic artifacts, assemblage I: 1 - core, 2-5 - selection of blades

Ryc. 3. Zabytki krzemienne, zbiór I: 1 - rdzeń; 2-5 - wybrane wióry

a direct percussion with a heavy, but relatively soft hammer. Most probably a soft mineral hammer (sandstone?) or antler billet was used for the detachment of blades. What is significant in this case, the force was applied to the platform, instead of the edge. 
Blades are rather irregular, quite thick and wide. The profile of most of them is slightly curved. In a few cases a slight deflection can be seen. Blade detachment was preceded by a slight abrasion, however in the light of materials available it seems that there was no rule as far as their application was concerned. In some cases, traces of a slight faceting and/or rejuvenation of the core can be seen. Core angles ranges from ca. 70 to $85^{\circ}$. There are no visible traces of repairs or corrections of the profile of the blades. The presence of cortex on some of the blades suggests hardly refined core preparation.

On the basis of debitage described here, it must be stated that the core from this assemblage has similar features. At least three series of blade detachment can be seen on its surface, the two earlier series mostly have hinge termination. This would suggest problems the producer had due to the lack of necessary skills. It needs to be highlighted that on the base and partially on the sides of the core the preparation negatives, definitely earlier than blade series, are clearly noticeable. The lack of visible butt negatives of platform rejuvenation strikes suggests, that the original core must have been considerably reduced.

It seems that from the point of view of the method applied, the kind and the quality of the raw material used were of secondary importance. The analysed assemblage comprised few types of flint of varied quality. It mainly includes Cretacious flint (primarily Upper Turonian flint of various types), although it is possible that at least a part of the finds was made of Jurassic flint.

The method applied needs to be characterised as rather negligent and simple. The creators of these objects had a limited knowledge of the flintknapping technology and the features of raw materials. Individual skills may be regarded as average but nonetheless satisfactory as far as the simplicity of the method applied is concerned.

Considering the technological prerequisites it seems that the assemblage described here might be the remains of the Bromme Culture concentration. Such an interpretation is supported by the form of the flint core and the use of direct percussion perpendicular to the platform. Despite the technological similarity, the size of the artifacts allows for dismissing any assumptions of their potential Early Mesolithic origin.

\section{Assemblage II: Pressure technique (?)}

Assemblage II comprises five pieces of technological waste. Due to lack of blades or typological tools the anthropogenic character of elements included in the group may raise some doubts. Therefore, the conclusions presented here need to be approached with great caution. 


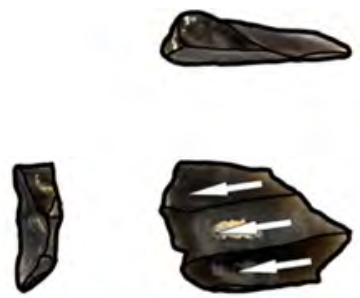

1

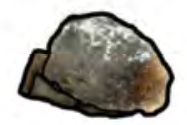

3
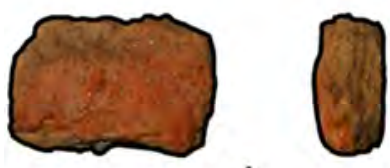

4

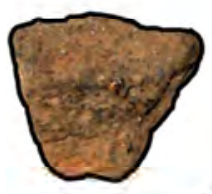

6

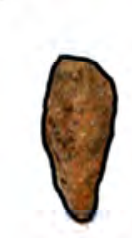

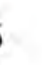
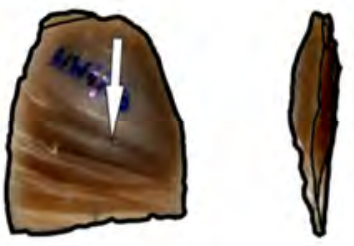

2
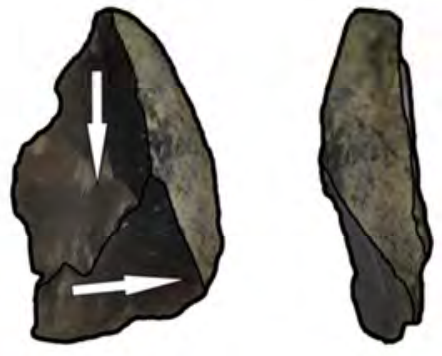

5

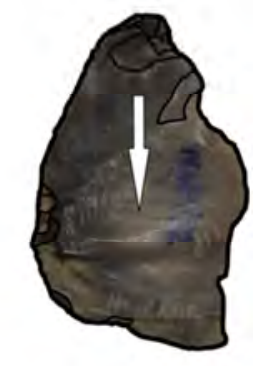

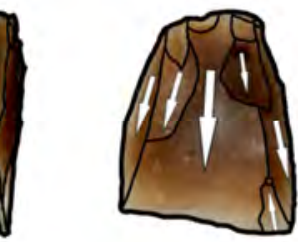
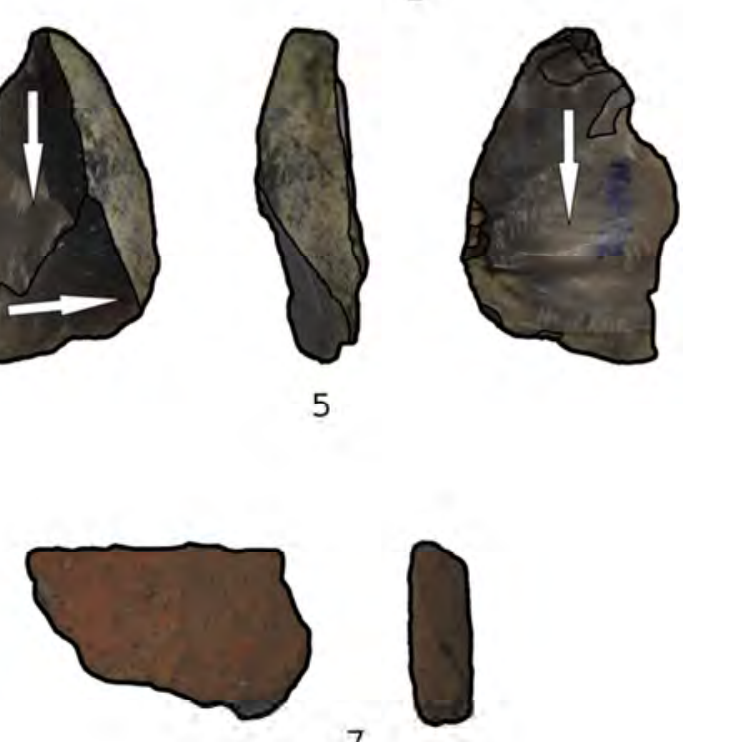

\section{7}
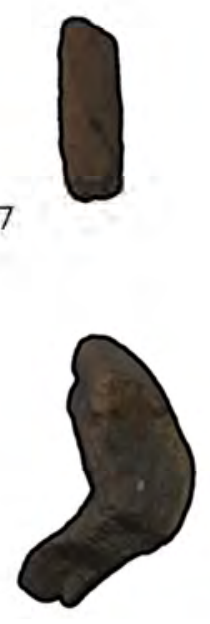

8

Fig. 4. Lithic artifacts, assemblage II: 1 - correction flake with pressure blades negatives on dorsal side, 3 - rejuvenation flake (?); assemblage III: 2, 5- bipolar flakes; pottery, assemblage I: 4, 6-7 - Lusatian Culture pottery; assemblage II: 8 - Post-Medieval pottery

Ryc. 4. Zabytki krzemienne, zbiór II: 1 - odłupek korekcyjny z negatywami wiórków naciskowych na stronie wierzchniej, 3 - świeżak (?); zbiór III: 2, 5 - łuszczki; ceramika, zbiór I: 4, 6-7 - ceramika łużycka; zbiór II: 8 - ceramika nowożytna 
The primary premise for distinguishing this group is the presence of the flake correcting the base of the pressure core. Its origin is evidenced by a series of minor, but very regular negatives of pressure blades. Unfortunately, nothing about the form of the core nor the way of pressure application can be said on the basis of this find.

With some degree of caution, four further finds can be associated with this particular artefact. They were interpreted as a waste from the correction of the platform of small cores. Considering their small sizes, they could be parts of pressure cores, and if that was the case then the finds could potentially be part of the same collection, just like the technological flake described above.

Due to the scarcity of material drawing more detailed conclusions on this collection is impossible. It might be associated with Middle Mesolithic period, although such an interpretation needs to be approached with due caution. In this case it might just be possible that these artefacts are associated with the older hearth.

\section{Group III: Bipolar/anvil technique}

A total of nine flakes were included in the collection, all of which display a similar set of features, the most distinctive of which are very clear, sharp ripples, crushed edges and lack of striking butts or edge butts. The features described here allow for considering the finds as compression flakes. The basic technique involved direct hard-hammer percussion while using a hard, mineral anvil.

The technique applied seems to be an exceptionally simple, or even primitive one. There are no remains of any preparation or repairs. Most probably the basic presumption was to obtain a sharp edge. Despite consisting of very few finds and the relative homogeneity of the discussed group it seems that the producers had very limited skills and knowledge on the ways flint could be processed.

Most probably, the group could be associated with the Lusatian culture from the Middle and the Late Bronze and the Early Iron Age. The application of simple methods of flint processing, including bipolar technique was quite popular in Lusatian flintknapping. With considerable caution it could be associated with younger hearth.

\section{POTTERY}

\section{Assemblage I: prehistoric pottery}

The group consists of fifteen pieces of handmade pottery. Unfortunately, the exacavated finds include unornamented pieces of bellies which makes the taxonomy of the group very difficult. 
The outer layers of the shards are orange, which indicates the oxidising atmosphere of firing. The fragments are quite fragile, which would point to firing in a primitive kiln, however at a temperature much higher than in an open fire. Medium grain breakstone is a compound in the clay. The compound is mixed in the clay quite irregularly. In a few cases it is possible to define the technique in which the pottery was formed. The basic technique is $\mathrm{N}$ technique, which is proved by overlapping subsequent layers of the clay body.

The thickness of the preserved fragments ranges from 0.8 up to $1 \mathrm{~cm}$, which together with other technological features allows for regarding the shards as fragments of the so-called coarse pottery.

All features of the pottery assemblage allows for ascribing it to Lusatian culture. Similarly to the group of flints made by using bipolar technique, it can be associated with the later hearth.

\section{Assemblage II: Post-Medieval pottery (?)}

This assemblage consists of 4 elements including 2 rims, a fragment of the body and a fragment a clay fishing weight.

The fragments of pottery from this assemblage belonged to vessels fired in a very high temperature, in reducing atmosphere, which shows in the grey colour of the surface. Fine grain sand was added, evenly mixed within the clay body.

The pottery may have been shaped by hand by pulling upwards a ball of clay placed on the potter's wheel. This shows in lines joining successive layers of clay parallel to the surface of the ware.

The sinker, from which the preserved piece comes, was fired in very high temperature, in oxidising atmosphere, which shows in the orange colour of the surface. Added components are mineral breakstone and fine grain sand. The components are mixed relatively evenly in the clay. It seems that the weight was formed by applying successive layers of clay on wooden core. After removing it, a hole was made for tying it to the nets.

The assemblage should probably be dated to Late Medieval or Post-Medieval times. A more precise dating is impossible due to the limited number of finds and their heterogeneity.

\section{PROBLEMS WITH INTERPRETING THE FINDS}

It needs to be admitted that the interpretation of the collected finds posed numerous problems on many occasions. Proper identification of the artefacts is of major importance. 


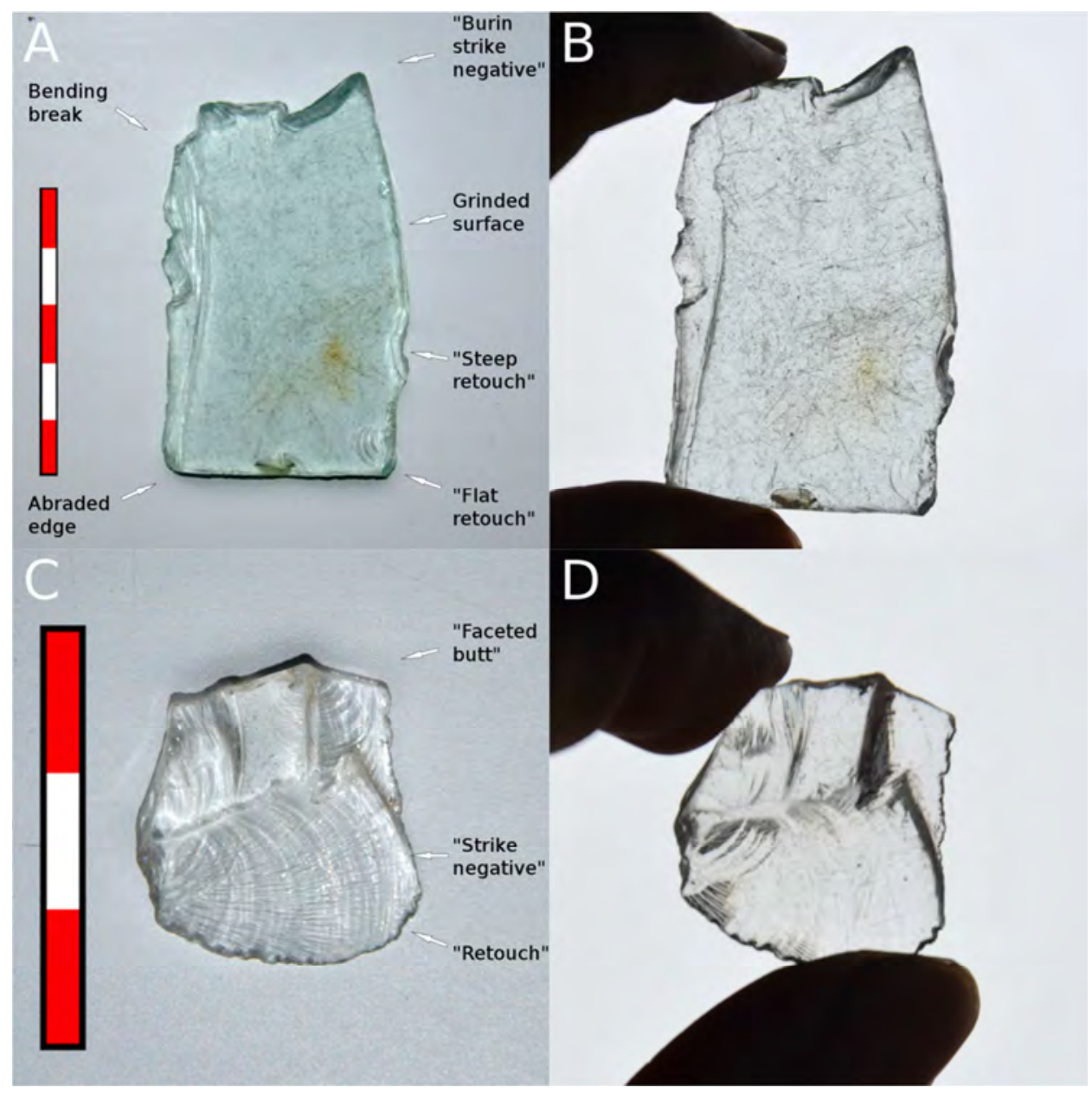

Fig. 5. Examples of post-depositional damages and eolithisation processes on Nowe Warpno site. A - Glass plate with various damages; C - "retouched flake" of bottle glass; B, D - the same objects seen the light

Note the differences of surface damages of the items. Both items were collected on the Nowe Warpno site.

Ryc. 5. Przykłady zniszczeń postdepozycyjnych i eolityzacji na stanowisku w Nowym Warpnie. A - płytka szklana z różnego typu zniszczeniami; C - „retuszowany odłupek” ze szkła butelkowego; $\mathrm{B}, \mathrm{D}$ - te same przedmioty widziane pod światło

Zwracają uwagę różnice w zniszczeniach powierzchni obu przedmiotów. Oba przedmioty zostały znalezione na stanowisku w Nowym Warpnie.

The context of deposition of the finds in the case described here needs to be defined as the environment of high energy of deposition. It means that the discussed artefacts (pottery, flint) deposited in this context are exposed to enormous forces. It 
needs to be emphasised that this phenomenon has a much wider context and is relevant to all of the portable material, including flint finds as well as natural chunks and the raw material pebbles. This circumstance is of paramount importance as it results in two separate processes:

- The creation of geofacts imitating artefacts;

- The destruction of artefacts (up to the point where determining their anthropogenic character is impossible).

These processes resulted in a rich collection of materials displaying unambiguous morphologic features. Their identification, and successive interpretation proved to be the biggest challenge at the level of analysis that was carried out.

Of course the problem of identification of artefacts as well as the influence of the elements of the environment on flint finds has been known for a long time now: the issue of the origin of the so called eoliths was extensively discussed already in the $19^{\text {th }}$ century. Such apparent artefacts were collected e.g. on Rügen Island (Adrian 1948; Deecke 1905; Drolshagen 1907). Recently attempts are made at solving the problem of identification and interpretation of post-deposition damage of flint finds by means of controlled experiments (e.g. Eren, Boehm, Morgan, Anderson and Andrews 2011; McBrearty, Bishop, Plummer, Dewar and Conrad 1998). However, depending on the conditions in which such experiments are carried out and the major presumption (e.g. trampling testing, the testing of damage in environments characterised by high energy of deposition) the results of such tests are ambiguous, and in some cases even mutually exclusive. Hence it is difficult to accept that this issue has been satisfactorily solved on the ground of archaeological methodology. It is for these reasons that we have decided to define our own presumptions of the method of analysis of such collections. We hope, however, that this suggestion has also some universal values, extending beyond the case of Nowe Warpno.

The primary action taken with regard to flint finds collected was their rigorous selection. Its purpose was to systematise and define the research value of analysed sources. Moreover, an assumption was made that it is better to draw conclusions on the basis of a relatively reliable, although limited collection, than to form generalised observations made on the basis of a collection which might be larger but in fact very syncretic. The total inventory was divided into four groups corresponding to the level of probability that each object is an artefact:

- Artefacts;

- Damaged artefacts;

- Eoliths/geofacts imitating artefacts;

- Geofacts.

Only the finds that have been included in the first two collections were subject to further research. However, finds included in groups three and four were considered a reference collection, to ensure the evaluation and proper qualification of further finds. For this reason this part of the collection of finds is of great significance both for current as well as future studies of this kind of inventory. 
On the descriptive level it needs to be said that the state of preservation of portable sources collected in Nowe Warpno is bad. The edges of most of the flint artefacts collected are severely damaged; also their surfaces are usually heavily polished, which on most occasions hampered the interpretation of strike directions. Due to the influence of coastline processes many finds were severely chipped. This process resulted in numerous chunks present among the finds, defined as natural fragments of flints separated from bigger anthropogenic forms.

It is worth noting that similar features were also observed on pottery shards. Hence considerable fragmentation of the pottery and strong wear of the surface and the edges need to be considered as the result of deposition in the seafront zone and on the beach.

In case of flint, the interpretation of retouched edges was particularly difficult. Because almost all flakes and blades have marks on edges, it was necessary to assess the probability that a particular retouch is anthropogenic. What is more, the possibility of working retouch also needed to be considered. In these circumstances an assumption was made that only retouch characterised by regularity and continuity on one side could be considered an intentional one. All scars not meeting the above criteria, e.g. irregular retouch found on both edges were considered non-intentional / non-anthropogenic ones.

Another major problem was the interpretation of compression flakes. It needs to be emphasised that apart from assemblage III, many finds displaying compression features were found (both debitage as well as 'core'). The problem is significant, because depending on methodological approach the same finds may be classified either as artefacts or geofacts. In this case a decision was made to adopt very strict criteria: only materials showing a negative scar pattern on their ventral side pointing to intentional strike from a core trimmed in series were classified as artefacts.

In conclusion it needs to be observed, that the premises accepted for the purpose of classification of flint finds resulted in a strong quantitative limitation of the analysed assemblage. Simultaneously, at this stage it is difficult to assess the 'dark number' of artefacts that could not be recognised due to the loss of all their anthropogenic features. It is hoped, however, that together with the increase of the assemblage of portable finds, it will be possible to introduce statistical procedures, which may offer a satisfactory answer to the various questions raised.

\section{RESEARCH ON SEAFRONT SITES, THEIR RESULTS AND IMPLICATIONS}

It seems that the site in Nowe Warpno has unique characteristics. On the one hand it is a classic land site, although its location on the cliff enforces specific methodological procedures during the exploration and documentation of archaeo- 
logical sources. On the other hand, however, portable finds are also excavated from marine environment, in contexts similar to ones known from the exploration of submerged landscapes. These circumstances may lead to a number of observations relevant to the archaeology of both these areas: land and water.

It is beyond any doubt that the exceptionally quick rate of damage to the cliff must have an influence on any studies on settlements in seaside areas. It is relevant to prehistoric periods in an obvious way. However, various examples of early medieval and medieval settlements may be given, where the context, or even the state of preservation changed following the abrasion of the nearby shore. The example of the village of Lubin presented above may be complemented by the example of the $14^{\text {th }}$ century church in Trzęsacz, of which only one wall standing on the edge of the cliff survived. In Nowe Warpno itself there is no early medieval stronghold, although there is a suburbium; hence assumptions are made that the structure was totally destroyed due to the shifting shore of the Lagoon.

Contemporary climatic changes result in the escalation of weather patterns, also in the temperate zone. Hence the rate at which coastlines are destroyed can be expected to accelerate. Likewise we may also expect coastline processes on stretches of land so far considered to be stable. It means that potentially more and more archaeological sites will face destruction.

In our opinion these factors require active responses from the archaeological community and the development of methodological schemes for future archaeological research on cliff coastlines in general. In this paper we disregarded all aspects related to the management of national heritage. In case of locations such as those discussed within this article, matters of both competence of relevant authorities as well as the hierarchy of priorities are reduced to the following dillema: should we protect the coastline and accept the destruction of archaeological environment or should we excavate the site and by doing so destroy the coastline. In the nearest future such choices will require relevant, legal regulations.

The preliminary stage of such work in the zone of active cliff should be a detailed preliminary research of archives combined with field survey. Its aim is to establish (or possibly register) archaeological sites currently located in the hinterland of the cliff, which could be subject to successive destruction by abrasion. However, not all sites can be easily revealed by the presence of artefacts on the ground level: the case of Nowe Warpno indicates that finds could be deposited from 1 up to 3 meters below today's ground level. The uncovering of such a site may take place no sooner than at the moment it is cut through by the landslip of the cliff. Hence a regular monitoring of the coast is necessary, taking into account weather conditions as well. Observations of the results of storms, thaw or intensive rainfall, which accelerate collapse and landslip are also of great significance. It is then that stratigraphic units and finds that under normal circumstances are not recognisable or incidental, can be established. 
It needs to be noted, that only vertical uncovering (cliff) in Nowe Warpno was subject to observation and recording, and that no exploration was possible. It meant that in that case we were neither able to excavate further finds in a methodical way, nor did we have any chance to explore bigger sources of portable finds from undisturbed contexts.

An important part of research on the cliff must also be a detailed observation and analysis of the mechanisms of the redeposition of portable sources. Artefacts collected in cultural accumulations slide to the beach at the bottom of the cliff, and then they are subject to the same processes of transport of mass material of the debris. It means that artefacts deposited in the secondary deposit appear in the zone of the abrasian platform. Their layout in space may be a hint as to the scale of destruction of the site, its primary range, as well as the rate of damage to the cliff and the speed and range of processes responsible for the transport of materials in flat shoal. Such research should be supported by studies on artefacts themselves, the state of their preservation and the influence of redeposition on the readability of anthropogenic features which they display.

As it can be seen, the research formula adopted above respects the priority of the protection of the coastline. It has been accepted that the solution allowing for immediate research is better than idle waiting for the results of legal and legislative action. It does not mean, however, that we do not recognise the need for regulating the question of protection of such sites and for defining the procedure of their exploration.

The processes observed in Nowe Warpno are possibly of even greater significance for the exploration of submerged landscapes. Artefacts found in underwater contexts might be the premise to register submerged sites, but their context must be obvious. Meanwhile, the phenomenon of redeposition of finds also includes shifts within the basin due to the flow of currents, waving, etc. As a result, it can lead to the multiplication of archaeological sites and their false identification in various parts of the basin. Such a situation seems to be very likely, especially in case of basin so active as the Szczecin Lagoon. It cannot be excluded that we quite often deal with such a situation when individual artefacts or their small assemblages are recognised during underwater exploration. It seems that in such cases a further specification of the status of the finds by examining the stratigraphy and analysing the whole littoral zone would be necessary. As mentioned above, studies of historical cartography which have the capacity of reconstructing former coastlines would also be useful.

\section{CONCLUSION}

The original research on submerged landscapes covered areas submerged as a result of rising water levels. The coastline shaped at the end of the period of transgression of the Littorina Sea was considered similar (and, in fact, identical) to the 
contemporary one. As a result it was accepted that artefacts deposited in flat shoals indicate archaeological sites located in these places.

Meanwhile, the case of Nowe Warpno drew our attention to the problem of destruction of seafront sites and the transport of portable archaeological material. The logical consequence of this research was to reflect on the context and the cognitive value of archaeological sources discovered in water. It became obvious, that redeposited artefacts could also be found within basins, for which water environment is a secondary context. Therefore, the presence of artefacts in water is not a premise for registering a submerged archaeological site. This statement could be of great significance both for contemporary as well as for future research within the shelf, as well as the verification of already recorded sites.

\section{REFERENCES}

Adrian W.

1948 Die Frage der Nordeutschen Eolithen, Ferdinand Schöningh. Paderborn.

Deecke W.

1905 Zur Eolithenfrage auf Rügen und Bornholm. Correspondenz-Blatt des Deutschen Gesellschaft für Anthropologie, Ethnologie und Urgeschichte, 26, pp. 26-32.

Drolshagen C.

1907 Primitive Handgeräte aus der Neuvorpommern und Rügens. Pommersche Jahrbücher, 8-9, pp. 17-48.

Dudzińska-Nowak J.

2007 Przydatność skanowania laserowego do badań strefy brzegowej południowego Bałtyku. Archiwum Fotogrametrii, Kartografii i Teledetekcji, 17a, pp. 179-187.

Eren M.I., Boehm A.R., Morgan B.M., Anderson R., and Andrews B.

2011 Flaked Stone Taphonomy: a Controlled Experimental Study of the Effects of Sediment Consolidation on Flake Edge Morphology. Journal of Taphonomy, 9 (3), pp. 201-217.

Lampe R.

2002 Post-glacial water-level variability along the south Baltic coast - a short overview. In

R. Lampe (ed.), Holocene Evolution of the South-Western Baltic Coast - Geological, Archaeological and Palaeo-environmental Aspects (pp. 13-20). Greifswald: Geographisches Institut der Ernst-Moritz-Arndt-Universität Greifswald.

McBrearty S., Bishop L., Plummer T., Dewar R., and Conrad N.

1998 Tools Underfoot: Human Trampling as an Agent of Lithic Artifact Edge Modification. American Antiquity, 63(1), pp. 108-129.

Migal W.

2007 On preferential points of the Final Paleolithic in the Central European Lowland. In:

M. Kobusiewicz and J. Kabaciński (eds.), Studies in the Final Paleolithic Settlement of the Great European Plain (pp. 185-200). Poznań: Institute of Archaeology and Ethnology, Poznań Branch, Poznań Prehistoric Society.

Miotk-Szpiganowicz G., Uścinowicz Sz., Przeździecki P., and Jegliński W.

2009 Reconstruction of the palaeo-lanscapes of the southern Baltic. MACHU Project Report, 3, pp. 80-84. 
Pelegrin J.

2006 Long blade technology in the Old World: an experimental approach and some archaeological results. In: J. Apel and K. Knutsson (eds.), Skilled Production and Social Reproduction. Aspects of traditional Stone-Tool Technologies, SAU Stone Studies 2 (pp. 37-68). Uppsala: Societas Archaeologica Upsaliensis \& The Department of Archaeology and Ancient History, Uppsala University.

Piasecki D.

1966 Wybrzeże polskie w świetle dawnych map. Zeszyty Geograficzne WSR Gdańsk, 8, pp. $27-72$.

Płaza D.K., Grużdź W.

2010 Experimental Study of Pomeranian Flint (Kugleflint). Some aspects of blade technology on Mesolithic site Jastrzębia Góra 4. Materiaty Zachodniopomorskie. Nowa Seria, 4/5, pp. 5-20.

Schoeneich K.

1964 Uzależnienie przebiegu linii brzegowej południowej części Bałtyku od budowy geologicznej. Zeszyty Naukowe Politechniki Szczecińskiej, 49 (Prace Monograficzne, 16), Szczecin.

Sørensen M.

2006 Teknologiske traditioner i Maglemosekulturen. En diakron analyse af Maglemosekulturens flækkeindustri. In: B.V. Eriksen (ed.), Stenalderstudier. Tidligt mesolitiske jagere og samlere i Sydskandinavien (vol. 55, pp. 19-75). Højbjerg: Jysk Arkæologisk Selskabs.

Spethman H.

1906 Ancylussee und Litorinameer im südwestlichen Ostseebecken von der danischen Granze bis zur Odermündung, Schmidt. Lubeck.

\title{
PRZYPADEK NOWEGO WARPNA - NOWY WYMIAR BADAŃ PODWODNYCH NA ZALEWIE SZCZECIŃSKIM
}

\author{
Streszczenie
}

\section{WSTĘP}

Autorzy niniejszego artykułu przedstawiają nowy aspekt badań nad krajobrazami zatopionymi na Zalewie Szczecińskim. Wszystkie badania wykonywane były w ramach projektu realizowanego przez Uniwersytet Szczeciński pt. „Archaeological and paleoenvironmental study of submerged landscapes in the Szczecin Lagoon and Pomeranian Bay". Projekt ten jest efektem naszego udziału w ogólnoeuropejskim programie współpracy naukowej SPLASHCOS, czyli Submerged Prehistoric Archaeology and Landscapes of the Continental Shelf.

\section{PRZYPADEK NOWEGO WARPNA}

Nowe Warpno jest miejscowością położoną w zachodniej części Zalewu Szczecińskiego. Interesujący nas odcinek brzegu ma formę klifu przecinającego serię pokryw eolicznych zalegających na starszych utworach plejstoceńskich. Na klifie wyróżniono kilka poziomów gleb kopalnych, 
jednak zasadniczym przedmiotem naszego zainteresowania były materiały archeologiczne zalegające u podstawy klifu oraz na płyciźnie w strefie sięgającej 20-30 m od tego odsłonięcia. Podjęto zatem procedury badawcze mające na celu ustalenie zasięgu ich występowania, cech dyspersji, kontekstu geologicznego (stratyfikacji) oraz uchwycenie ich kontekstów antropogenicznych. Szybko stało się jasne, że zasadnicze konteksty, z którymi pierwotnie związane były rejestrowane źródła, występują na klifie, a nie na plaży u jego podstawy. Tam więc skoncentrowano główne wysiłki w pracy terenowej.

\section{BADANIA W NOWYM WARPNIE}

Prace podjęte na klifie pozwoliły na wydzielenie czterech poziomów gleb kopalnych. Dwa poziomy młodsze zinterpretowano jako rezultat zniszczenia szaty roślinnej w czasach nowożytnych (współczesnych). Najpewniej są one związane z gospodarką leśną (wyrębem drzew). Natomiast dwa starsze poziomy gleb kopalnych uznano za interesujące z punktu widzenia archeologii tym bardziej że w kontekście jednego z nich zaobserwowano wyraźnie czytelny obiekt archeologiczny. Przygotowany i oczyszczony profil został zadokumentowany, ponadto $z$ najstarszego poziomu glebowego oraz z wypełnisk obiektów pobrano próbki do badań paleośrodowiskowych oraz datowań. W tym celu wykonano analizę palinologiczną oraz datowanie metodą AMS. Zebrano również kolekcję źródeł ruchomych zalegających na plaży oraz na płyciźnie. Materiały te poddano analizie technologicznej.

\section{DATOWANIE AMS}

Datowaniu radiowęglowemu poddano trzy próbki. Jedna pochodziła $\mathrm{z}$ warstwy gleby kopalnej, kolejne dwie zaś z obiektów rozpoznanych w klifie. Badania wykonane przez Poznańskie Laboratorium Radiowęglowe pozwoliły uzyskać następujące rezultaty:

$-11060 \pm 60$ BP [Poz-44487], gleba kopalna: $11001 \pm 107$ BC cal;

$-8700 \pm 50$ BP [Poz-44489], starsze palenisko: $7717 \pm 77 \mathrm{BC}$ cal;

$-2430 \pm 35$ BP [Poz-44488], młodsze palenisko: $575 \pm 129 \mathrm{BC}$ cal

(Wszystkie daty zostały skalibrowane z użyciem CalPal_2007_HULU curve: Danzeglocke U., Jöris O., Weninger B., 2012. CalPal-2007online. http://www.calpal-online.de/, 2012-02-04).

Powyższe wyniki pozwalają wyróżnić co najmniej dwa epizody osadnicze. Pierwszy z nich, wyróżniony na podstawie daty ze starszego paleniska, należy identyfikować z okresem środkowego mezolitu, a konkretnie z kulturą Maglemose. Drugi epizod należy datować na początek epoki żelaza i łączyć go można z kulturą łużycką. Omawiane rezultaty w dalszej części odnieśliśmy do analiz zabytków archeologicznych.

\section{RUCHOME ŹRÓDŁA ARCHEOLOGICZNE}

W ramach badań na klifie, na plaży i w strefie brzegowej w rejonie stanowiska zebrano kolekcję artefaktów krzemiennych oraz fragmentów ceramiki. Roboczo dokonano podziału zabytków na zbiory. Na podstawie analizy technologicznej wydzielono 3 zbiory zabytków krzemiennych. Analogiczna procedura zastosowana do kolekcji ceramiki pozwoliła wydzielić dwa zbiory, z których jeden może być wiązany (korelowany) z jednym ze zbiorów zabytków krzemiennych. 


\section{ZABYTKI KRZEMIENNE}

- Zbiór I: 15 wiórów uderzanych bezpośrednio relatywnie miękkim tłukiem, wraz z rdzeniem - najprawdopodobniej jest to pozostałość po krzemienicy kultury Bromme, choć nie można też wykluczyć wczesnomezolitycznego datowania.

- Zbiór II: 5 odpadów technologicznych, najprawdopodobniej łączonych z wykorzystaniem techniki naciskowej. Ostrożnie można go datować na środkowy mezolit, choć nie sposób określić relacji tego zbioru ze starszym paleniskiem.

- Zbiór III: 9 odłupków kompresyjnych; prawdopodobnie należy łączyć ten zbiór z kulturą łużycką ze środkowej i późnej epoki brązu oraz wczesnej epoki żelaza, podobnie jak część ceramiki oraz młodsze palenisko.

\section{CERAMIKA}

- Zbiór I: 15 fragmentów ceramiki lepionej ręcznie. Powierzchnie zewnętrzne skorup mają barwę pomarańczową. W obrębie masy ceramicznej domieszka rozprowadzona jest dość nieregularnie. Najprawdopodobniej jest to ceramika kultury łużyckiej, podobnie jak zbiór odłupków kompresyjnych łączona jest z młodszym paleniskiem.

- Zbiór II: 4 elementy, wśród których są 2 wylewy, fragment brzuśca oraz fragment ceramicznego ciężarka do sieci. Fragmenty ceramiki pochodzą z naczyń wypalonych w bardzo wysokiej temperaturze, w atmosferze redukcyjnej, o czym świadczy siwa barwa powierzchni. Domieszkę stanowi drobnoziarnisty piasek, równomiernie rozprowadzony w obrębie masy ceramicznej. Zespół ten prawdopodobnie należy datować na okres późnośredniowieczny lub nowożytny.

\section{PROBLEM INTERPRETACJI ZABYTKÓW}

Należy przyznać, że interpretacja zebranych materiałów niejednokrotnie sprawiała wiele problemów. Wśród nich na pierwszy plan wysuwa się zagadnienie prawidłowej identyfikacji artefaktów.

Kontekst zalegania zabytków w opisywanym przypadku należy określić jako środowisko o wysokiej energii depozycji. Oznacza to, że na artefakty (ceramikę, krzemienie) zalegające w tym kontekście oddziałują ogromne siły. Wypada zaznaczyć, że zjawisko to ma charakter szerszy i dotyczy ogółu materiałów ruchomych - wśród nich zarówno zabytków krzemiennych, jak i naturalnych okruchów oraz konkrecji krzemienia.

\section{BADANIA NA STANOWISKACH NADBRZEŻNYCH, ICH WYNIKI I IMPLIKACJE}

Jak się wydaje, stanowisko w Nowych Warpnie ma cechy wyjątkowe. Z jednej strony jest to klasyczne stanowisko lądowe, choć jego lokalizacja na klifie wymusza szczególne zachowania metodyczne w czasie eksploracji źródeł archeologicznych i ich dokumentacji. Z drugiej jednak strony materiały ruchome $\mathrm{z}$ tego stanowiska znajdowane są też w środowisku wodnym, w kontekstach zbliżonych do znanych z badań krajobrazów zatopionych. Okoliczności te mogą prowadzić do wielu spostrzeżeń odnoszących się do archeologii obu tych obszarów - lądowego i wodnego.

Procesy obserwowane w Nowym Warpnie mają ogromne znaczenie dla badań krajobrazów zatopionych. Artefakty znajdowane w kontekstach podwodnych mogą być przesłanką do rejestrowania stanowisk zatopionych, jednak ich kontekst musi być oczywisty. Tymczasem zjawisko re- 
depozycji zabytków obejmuje również przemieszczenia w obrębie zbiornika wodnego stosownie do układu prądów, falowania itd. W efekcie może to doprowadzić do multiplikacji stanowisk archeologicznych i ich błędnego identyfikowania w różnych częściach akwenu. Sytuacja taka wydaje się wysoce prawdopodobna, szczególnie w przypadku akwenów tak dynamicznych jak Zalew Szczeciński. Niewykluczone, że mamy do czynienia z taką sytuacją relatywnie często, gdy w ramach badań podwodnych w pobliżu brzegu rozpoznawane są pojedyncze artefakty lub ich niewielkie skupiska. Wydaje się, że w takich przypadkach konieczne byłoby również dookreślenie statusu tych źródeł poprzez rozpoznanie towarzyszącej im stratygrafii oraz analizę budowy całej strefy litoralnej. Przydatne mogą być także studia z zakresu kartografii historycznej, odtwarzające przebieg dawnych linii brzegowych, o których wspomniano wyżej.

\section{ZAKOŃCZENIE}

Pierwotnie badania krajobrazów zatopionych obejmowały obszary zalane na skutek podniesienia się poziomu wody. Przebieg linii brzegowej ukształtowanej wraz z końcem transgresji litorynowej uznawano przy tym za zbliżony (a w istocie - identyczny) do obecnego. W konsekwencji milcząco przyjęto, że artefakty zalegające w strefach płycizn są wyznacznikami znajdujących się tam stanowisk archeologicznych.

Tymczasem przypadek Nowego Warpna zwrócił naszą uwagę na problem niszczenia stanowisk przybrzeżnych i transport pochodzących z nich materiałów ruchomych. Logiczną konsekwencją tych badań była refleksja nad kontekstem oraz wartością poznawczą źródeł archeologicznych rejestrowanych w wodzie. Oczywiste stało się, że w obrębie zbiorników wodnych mogą znajdować się również artefakty redeponowane, dla których środowisko wodne jest kontekstem wtórnym. Obecność artefaktów w wodzie nie jest zatem wystarczającą przesłanką do rejestracji zatopionego stanowiska archeologicznego. Stwierdzenie to może mieć duże znaczenie zarówno dla bieżących i przyszłych badań w obrębie szelfu, jak i dla weryfikacji stanowisk już wyróżnionych. 